\title{
An Idea of Higher Education Renewal
}

\author{
By Marija Liudvika Drazdauskiene*
}

\begin{abstract}
Beginning with the briefest reference to the state of higher education today, this paper overviews moral and philosophical concepts of and disposition to education in ancient Greece from the works of Plato and Aristotle, takes a summary view of the subjects taught, sums up the subject content of liberal arts and the principles of rhetoric. The author assumes that even if a dedicated return to the classical ideals may never happen in higher education today, a few concrete ideas might be helpful. With reference to concrete works of classical authors, a suggestion is made to stop never-ending reforms in universities, to recover the teaching of such subjects as style in language and literature programmes, to renew the subjects of history, philosophy and logic and to introduce memory-based learning while paying tribute to classical antiquity and regaining local traditions.
\end{abstract}

\section{Introduction: The Problem and the Approach}

The problem of present-day higher education and why it has to be discussed is the loss of inherited, time-tested orientation through the unprecedented growth of knowledge in and information from sciences, through the extension of mass media and popular culture, through the inflation of knowledge in "the overinformed world" in which professionals lack the certainty and trust in themselves to take responsibilities. The loss of orientation is due to insufficient respect for professors in authority and to the fallen ethical, moral and academic standards.

This paper is of a potential renewal of higher education, not of innovation or reform. The idea is to suggest a direction of focus to what had been accepted in education but came to be ignored in the long run or was lost in present-day reforms and to what may be borrowed from the ideas of classical antiquity, which always retained its genuine insight and irreplaceable authenticity. The word 'renewal' has been borrowed from the James G. Martin Center for Academic Renewal (https://www.jamesgmartincenter/).

Although there was no higher education of the present-day model in classical antiquity, a number of conceptions and caveats known in classical antiquity are applicable today. Some of the precepts of classical antiquity have been retained, although impoverished, in present-day higher education.

Modern higher education has certain features, sometimes acknowledged only formally, which were treated as values in classical antiquity. For instance, in The Laws, Plato defined upbringing as that (activity which) leads a citizen to

"Professor, Wszechnica Polska, Poland. 
becoming virtuous and obliges him to desire to become more virtuous, to perfect himself, to live, to rule and to subject himself to the law ${ }^{1}$. Some of these features are formally acknowledged in present-day education and distorted while putting too great an emphasis on freedom without any regard to responsibilities in small countries of new democracies.

\section{The Principal Classical Concepts of Education}

According to Plato, education is required for the educated to be able to decide for themselves rather than to resort to strangers in decision making and "to let them be your masters and judges" 2 This concept is based on a true idea of freedom.

Aristotle assumed that education of youth should be foreseen and regulated by the law, should be one for all and should be executed under the law. Aristotle further posited that, "depending on the singular goal of the state, education should be one and obligatory to all. It should not be private when everyone teaches privately whatever he chooses" 3 .

Present-day higher education is regulated by the law in numerous countries, yet this bears little semblance to the classical concept because of corporate, lobbyist and social interference rather than genuine support.

Aristotle mentions discussions of the content of education, i.e discussions about what should be taught. There was no agreement on this then ${ }^{4}$. This question in classical antiquity concerned the subjects in the sense that classical

1. "Plato, The Laws," (trans.) A. Kudulyte-Kairiene, in Dilyte, 1991, 96.

2. "Does it not seem to you a scandalous thing, and a strong proof of defective education, to be obliged to import justice from others, in the character of lords and judges, in consequence of the scanty supply at home? Nothing can be more scandalous" (Plato, The Republic, Book III, 405ff).

3. "And just as there must also be preparatory training for all skills and capacities, ..., it is obvious that there must also be training for the activities of virtue. But since there is but one aim for the entire state, it follows that education must be one and the same for all, and that the responsibility for it must be a public one, not the private affair which it now is each man looking after his own children and teaching them privately whatever private curriculum he thinks they ought to study. In matters that belong to the public, training for them must be the public's concern" (Aristotle, The Politics, Book VIII. i, 1337a11-1337a32). "It is clear that there should be law laid down about education, and that education itself must be made a public concern" (Aristotle, The Politics, Book VIII. ii, 1337a33).

4. "But we must not forget the question of what that education is to be, and how one ought to be educated. For in modern times there are opposing views about the tasks to be set, for there are no generally accepted assumptions about what the young should learn, either for virtue or for the best life; nor yet is it clear whether their education ought to be conducted with more concern for the intellect than for the character of the soul" (Aristotle, The Politics, Book VIII. ii, 1337a33). 
authors deliberated on whether the required subjects were to be those which "develop thinking skills or the character of the soul", those that were useful in daily life or those that led to abstract knowledge ${ }^{5}$. Aristotle himself suggested a fair solution: "It is doubtless that useful things should be taught".

But Aristotle further mentioned that there is education which is required for sons not because it is useful in practical life and so necessary but "because it suits a free man and is beautiful in itself"7.

The discussion continues today and leads to an extreme emphasis on practical things (such as technical execution in manual work or commercial subjects in the humanities at university). The question remains whether this solution is an optimal issue. Without indicating direct cause and consequence relations, classical antiquity had an unarguable position on this. As society divided into free men and slaves, Aristotle thought that "the young should be taught those things that would not turn them into amateur performers and craftsmen. The amateur's activity was such an engagement, craft or learning which precluded the use of the mind, body and soul the way that is required of a free man, in his virtuous work and engagement" ${ }^{\prime \prime}$. Amateur engagements were those which diminish the body and make the mind and soul unfit for virtuous

5. "The problem has been complicated by the education we see actually given; and it is by no means certain whether training should be directed at things useful in life, or at those conducive to virtue, or at exceptional accomplishments. (...) And there is no agreement as to what in fact does tend towards virtue. For a start, men do not all prize the same virtue, so naturally they differ also about the training for it" (Aristotle, The Politics, Book VIII, ii, 1337a33).

6. "Then as to useful things: there are obviously certain essentials which the young must learn; but it is clear (a) that they must not learn all useful tasks, since we distinguish those that are proper for a free man and those that are not, and (b) that they must take part only in those useful occupations which will not turn the participant into a mechanic" (Aristotle, The Politics, Book VIII. ii, 1337b4). "It is also clear that there are some useful things, too, in which the young must be educated, not only because they are useful (for example they must learn reading and writing), but also because they are often a means to learning yet further subjects" (Aristotle, The Politics, Book VIII, iii, 1338a17).

7. Aristotle, The Politics, Book VIII, ii.

8. "We must reckon a task or skill or study as mechanical if it renders the body or intellect of free men unserviceable for the uses and activities of virtue. We therefore call mechanical those skills which have a deleterious effect on the body's condition, and all work that is paid for. For these make the mind preoccupied (without leisure), and unable to rise above lowly things. Even in some branches of knowledge worthy of free men, while there is a point up to which it does not demean a free man to go in for them, too great a concentration on them, too much mastering of detail - this is liable to lead to the same damaging effects that we have been speaking of. In this connection the purpose for which the action or the study is undertaken makes a big difference" (Aristotle, The Politics, Book VIII, ii, 1337b4). 
work. Base engagements were those which money buys ${ }^{9}$. This seems too nice to be neglected today, if only we could aspire to such heights.

It may be assumed, to illustrate, that crafts or DIY activities encouraged today would have been amateur activities for Aristotle, whereas services, which were paid slaves' work, would have been base engagement for a free man in classical antiquity. There are worse cases which may illustrate the point of engagements of the present-day. To commit a young talented girl to multiply printed texts in a foreign language by a mechanical typewriter without instructing her first in the basic knowledge of that foreign language is committing the person to an amateur activity for a miserable pay. To subject a highly educated woman to unemployment because she rejected advances and, later, to deny the person academic titles and to abuse her grandchildren for her rejection of the advances and harassment at a pre-retirement age are base activities. There are more examples of base activities, "which money buys" today, and the most obvious would be plagiarism and the supply of students' degree papers for a payment (online and in person). The negative evaluation of classified work in antiquity indicates how distanced the concepts of humanitarian values and morality have been between then and now.

Classical authors recommended to select the best schools and the best teachers for the young and the best works to be used in school. Classical antiquity had the concept of "a decent man" and had it uppermost in their mind whether they wrote about teachers, orators or philosophers. The initial schooling had to be based on the best selected works of literature and attended by the best teachers as the beginning was the most important for "a young tender being": it is at the beginning that the features which may be desirable to burgeon in the young take $\operatorname{root}^{10}$.

Never letting ethic and morality slip from their mind, authors of classical antiquity highlighted gratitude as a treasure: "the gratitude of a decent man for a kind turn is a real treasure". Amid the precepts to respect wealth, but only moderately, Isocratus reasoned that it is worthy to aspire to the best while being content with what one has ${ }^{11}$.

Aristotle further posited that there is a limit to which man remains free in his engagements and learning. Too deep and too meticulous engagement and research were not considered good as such engagements tended to the slave's

\section{See footnote 8 .}

10. "Then are you aware, that in every work the beginning is the most important part, especially in dealing with anything young and tender? For that is the time when every impression, which one may desire to communicate, is most readily stamped and taken" (Plato, The Republic, Book II, 377).

11. Isocratis Orationes: ПIPO $\Sigma \triangle \mathrm{HMONIKON,} \mathrm{I.27-29.}$ 
work. Plinius Secundus also noted of the assumption that it is not required to read much; it is rather required to read diligently ${ }^{12}$.

These and other similar precepts have not gone unnoticed. In his excellent practical study, Style, a British classicist, F. L. Lucas, gave his judgment on and recommendation of what is required of education, which is to know the best ${ }^{13}$.

Today, we have a similar aspiration in the name of creativity included in the $21^{\text {st }}$ century skills, among which creativity features significantly. However, the background and foundations differ in the concept of a creative man. As has been mentioned, apart from the concept of a free man, classical authors questioned how much the subjects taught contribute to the development of the soul or intellect, which is gone today. We think we know more of intellect, body and economy, but the character of the soul has slipped from our thinking and philosophical bias has gone out of all reasoning.

In the question of the subjects taught, classical authors referred to their essential conception of education: education "should add up to what may be lacking from birth (nature)"14. In early education, imitation, listening to stories and observing lessons initially should feature at the start. Imitation should follow only the virtuous and the best examples. Plato demanded that stories for children had the required harmony. Hence was the requirement of the classics to select what works should be used in education and what should not, as first impressions were the most powerful ${ }^{15}$. A child had to be directed to virtue from tender years and had to develop a desire to perfect oneself ${ }^{16}$. This principle

12. Pliny, Fifty Letters of Pliny. Second Edition. (Selected and ed.) A. N. Sherwin-White (Oxford, New York: Oxford University Press), Letter 36 (VII.9).

13. "... what matters at school, at the University, and in after-life is not new interpretations of Shakespeare - they are usually false; not new theories of criticism - they are usually futile; but a knowledge of the best that has been said or written, and the power - I admit the limited extent to which this can be taught - to speak and write." (F. L. Lucas, 1955, 25-26).

14. "For those who divide life into periods of seven years are not far wrong and we ought to keep to the division that nature makes. For all skill and education aim at filling the gaps that nature leaves" (Aristotle, The Politics, Book VII, xvii).

15. See footnote 10, above. Cf.: "He (Theodorus, the tragic actor) never allowed any other actor, even quite an inferior one, to appear on the stage before him - because, he said, an audience always takes kindly to the first voice that meets their ears. The same thing is true of men's relations both with each other and the things they encounter: we always delight more in what comes first" (Aristotle, The Politics, Book VII, xvii).

16. "But if there is any possibility of persuading them, that to quarrel with one's fellow is a sin of which no member of a state was ever guilty, such ought rather to be the language held to our children from the first, by old men and old women, and all elderly persons, and such is the strain in which our poets must be compelled to write. /... ..., we ought to esteem it of the greatest importance that the fictions which children first hear should be adapted in the most perfect manner to the promotions of virtue" (Plato, The Republic, Book II, 378). 
excluded and forbade immoral pictures and stories. The argument was: "If bad speech is forbidden, so should be inappropriate views and performances"17.

The fights and wrangling of Gods even in Homer were not a becoming literature for the young. It took an adult man to learn of Gods' escapades ${ }^{18}$. Plato's decision on poets was quite rigorous: Plato suggested that the representation of Gods had to follow certain rules: (1) it was required that the poets represented Gods as they are, whether in epic, lyric or tragedy, because "nothing that is good is hurtful". Further reasoning led to the assumption, that, "being good, God couldn't be the cause of everything and was not guilty of many things, as good was scarcer than evil"19. The reason of good is definitely God and the reasons of evil are to be sought elsewhere" 20 . The second rule in the representation of Gods by the Poets stated that the Poets should not fantasise about Gods and scare the children. It was required not to treat Gods like magicians who change their shapes, "go about by night in the likeness of strangers from every land", scare and "foster timidity in their children". Gods do not change their shapes and do not deceive us either by word or action ${ }^{21}$. Disobedient poets were not suitable as children's literature and were to be "ousted from the state". Plato suggested that poetry, even that of Homer, could be expunged. Such lines which blacken Hades and magnify horrors are "neither true nor beneficial to men who are intended to be warlike"22. Some praise, it was believed, would be more useful ${ }^{23}$.

17. "The legislator ought to banish utterly from the state, as he would any other evil, all unseemly talk; for the unseemly talk lightly dropped results in conduct of a like kind. Especially, therefore, must it be kept away from youth: let them not hear or see anything of that kind" (Aristotle, The Politics, Book VII, xvii, 1336b3).

18. "And since we exclude all unseemly talk, we must also forbid gazing at debased paintings or stories. Let it therefore be a duty of the rulers to see that there shall be nothing at all, statue or painting, that is a representation of unseemly actions, except in the shrines of certain gods (Notably Dionysus) whose province is such that the law does actually permit scurrility. The law further allows men who have reached the appropriate age to pay honour to these gods on behalf of their wives, their children and themselves" (Aristotle, The Politics, Book VII, xvii).

19. "If that be so, then God, in as much as he is good, cannot be the cause of all things, according to the common doctrine. On the contrary, he is the author of only a small part of human affairs; of the larger part he is not the author: for our evil things far outnumber our good things: and the good things we must ascribe to no other than God, while we must seek elsewhere, and not in him, the causes of the evil things" (Plato, The Republic, Book II, 379).

20. Plato, The Republic, Book II, 379.

21. Ibid, 381

22. Plato, The Republic. Book III, 387.

23. "These verses, and all that are like them, we shall entreat Homer and the other poets not to be angry if we erase, not because they are unpoetical, so much the less ought they to be recited in the hearing of boys and men, whom we require to be freemen, fearing slavery more than death" (Plato, The Republic, Book III, 387). 
"The upbringing which aims at gaining money, influence or other deceitful, senseless and wrong activity" was not "worthy of the name of education" 24 . Aristotle weighed in saying that it was least becoming to free people and people of magnanimous spirit to look for profit in everything ${ }^{25}$. Plato specified further saying that "future expectations meant hope, the expectation of suffering bred fear and that of pleasure courage". Reason ruled above all these and decided what was better and what was worse. Further, "reason, which is the common precept of the state", becomes the law, in Plato's understanding ${ }^{26}$. Referring to Pericles in Socrates's name, Xenophon thought that "laws is everything what has been decided by the collective meeting of the people and put down, and which determine what may be done and what may not" 27 . More specifically, Pericles was said to have claimed that "the law is what the government of the state decides and fixes in writing on what is obligatory" 28 . Classical authors aspired to beauty and moderation, sought law and order. This was important as they tended to base education, as mentioned earlier, moral and immoral behaviour, on law. As we hear from the President of ATINER, the classical dicta of moderation, law and beauty are the living rules in Greece today. It is mainly because of that that this presentation has been prepared for this particular Conference, in Greece and I gratefully acknowledge the invitation.

As we understand it today, we do not deny the rule of reason in the state organization of education, its administration, curriculae and in teaching, but trust in authority and therefore respect for reason are gone. We have many speakers, no authorities and no respect for authority, whatever their reason and intention. We no longer aspire to, absolutely, the best. There has even been a Guardian publication online in which, guided by a fixed premise, André Spicer (2019) argued that excellence and being outstanding are overrated and that being good enough, whether in schools, health service and in other spheres, is perfectly sufficient ${ }^{29}$.

24. Plato, The Laws, I.643-644.

25. "',', some useful things /.../ are often the means to learning yet further subjects. Similarly they must learn drawing, not for the sake of avoiding mistakes /.../ but rather because it teaches one to be observant of physical beauty. But to be constantly asking 'What is the use of it?' is unbecoming to those of broad vision ('magnanimous') and unworthy of free men" (Aristotle, The Politics, Book VIII, iii, 1338a37).

26. Plato, The Laws, I.643-644.

27. Xenophon, The Memories of Socrates, I.2.

28. Ibid.

29. André Spicer, Excellence is Overrated. Let's Embrace being Good Enough Instead (The Guardian, 2019). 


\section{Highlights of Primary Education in Classical Heritage}

Classical authors have left a very definite description of the initial or primary education. Upbringing should be executed through fine arts and gymnastics, as they "train body and soul" 30 . A man who manages both these subjects for the good of his soul may be considered to have a perfect achievement and to be an excellent creator of harmony ${ }^{31}$. The focus on good for the soul drawn from education was not a formal point in classical antiquity. It was a belief. Plato has extensive deliberation on the essence and being of the soul in his different works ${ }^{32}$, and this has special meaning in his concept of education. In Phaedrus ${ }^{33}$, Plato elaborates on the immortality of the soul, which it owes to its ceaseless movement ${ }^{34}$. The power of the soul is magnified owing to its wings in Plato's concept. Wings are there to lift up the soul to what is divine, beautiful, wise and good. Because of this attachment to the good, wings separate the soul from what is low and miserable ${ }^{35}$. The soul can be compared to a winged two-horse chariot and its driver. It is the soul who moves the chariot but the two horses in the soul's power are different: one is a good horse of commendable heritage, while the second is its opposite and the charioteer's work is hard and exhausting.

The winged soul itself flies in the skies and issues its influence over the world. But if it loses its wings, it whirls around until it hits upon something hard, settles in the thing and identifies with its earthly body, which, moved by the soul, seems to be moving on its own. This unity was given the name of a mortal. The immortal, on the contrary, has body and soul etternally bound together. It is only we, imperfect in our thinking, who represent God as some immortal entity of body and soul ${ }^{36}$.

The loss of the wings is a major cause of transformations in the soul for Plato, as is the upbringing of the soul in education ${ }^{37}$. Arguing about the influence of a lover, who is usually subjugating, faithless and envious, Plato gives preference to the indifferent other and warns of the unbecoming education of the soul, which is the highest virtue in itself ${ }^{38}$. The soul has to feed on the best of choices. That is

30. Plato, The Republic, Book III, 411.

31. "Then whosoever can best blend gymnastic with music and bring both to bear on the mind most judiciously, such a man we shall justly call perfect in music, and a master of true harmony, much rather than the artist who tunes the strings of the lyre" (Plato. The Republic, Book III, 412).

32 Plato, The Great Dialogues of Plato (trans.) W. H. D. Rouse (ed.) Eric H. Warmington and Philip Rouse (New York: A Mentor Book from New American Library, 1956).

33. Plato, Faidras (trans.) Naglis Kardelis (Vilnius: Aidai, 1996).

34. Ibid, 245b-d.

35. Ibid, 246c-d.

36. Ibid, 246b-c.

37. Ibid, 241b-d.

38. Ibid, 241b-c-d. 
why, the young have to be taught only select subjects by the best teachers, read selected works, avoid the ugly and unbecoming. It has to be stressed in this context again that the emphasis on the good for the soul as a divine entity in education was an integral part of belief rather than that of a method to Plato. Importantly, the good of the soul extended further to the decency and honour of a free man in classical antiquity.

\section{Highlights of Schooling in Classical Heritage}

Concerning subjects, arithmetic and geometry were found very useful and were taught as obligatory to the persons "who are destined to take part in the weightiest affairs of state" ${ }^{\prime 39}$, while liberal arts and gymnastics were equally fitting to men and women, although their physical strength could differ ${ }^{40}$. Alluding to the knowledge of the efficiency of a Sarmatian woman, Plato claimed that "men and women should be trained in equal measure" because "the state diminishes if men and women are separated in training" 41 "No free man should learn any science like a slave" because "compulsory knowledge is weak"42. Education should cultivate reason which is to search further, "instead of trusting the senses, which provide nothing for certainty" 43 .

It was customary, wrote Aristotle, to teach grammar, gymnastics, music and drawing to young children. Aristotle considered music to be the beginning of everything 44 and the art which creates pleasant leisure. Plato argued similarly of music but criticised poetry and the poets quite rigorously. The age of schooling divided thus: up to 5 years of age, a child had to be taught at home. From 5 to 7 years, he had to observe lessons of the subjects he was to learn later. From 7 to 21, education was secondary and deficiencies of nature attended to, "For all skill and education aim at filling the gaps that nature leaves" 45 . Alongside, the same authors posited that children should be taught through games, but only in tender

39. Plato, The Republic, Book VII, 525ff.

40. Ibid, Book V, 482.

41. Plato, The Laws, XII.

42. "Arithmetic, therefore, and geometry, ... to pave the way for dialectic, must be taught our pupils in their childhood; - care being taken to convey instruction in such a shape as not to make it compulsory upon them to learn. /.../ Because, I replied, no trace of slavery ought to mix with the studies of the freeborn man. For the constrained performance of bodily labours does, it is true, exert no evil influence upon the body; but in the case of the mind, no study, pursued under compulsion, remains rooted in the memory" (Plato, The Republic, Book VII, 536.

43. Plato, The Republic, Book VII, vii.

44. Aristotle, The Politics, Book VIII, ii.

45. Ibid, Book VII, xvii. 
age. Teenagers were not to have a leisurely life ${ }^{46}$. Later, Seneca (1991) hinted at life-long learning while emphasising that the young have to learn the most ${ }^{47}$. Xenophon characterised his friends and man who is worthy of respect: it is "he who knows what is required to know and can express it in words" 48 . This dicta features in an inherited definition of good education to this day.

\section{Insights into Higher Education Drawn from Classical Heritage}

The subjects singled out by Plato, (gymnastics, grammar, arithmetic, geometry and astronomy), and by Aristotle, (grammar, rhetoric and dialectic/ logic, music and painting), and mentioned above developed later into septem artes liberales, which were studied by senior young men. Septem artes liberales later $\left(5^{\text {th }}\right.$ $6^{\text {th }}$ century AD) divided into trivium (grammar, rhetoric and dialectic) and quadrivium (music, arithmetic, geometry and astronomy), which were studied in Medieval universities ${ }^{49}$. The concept of liberal arts has been retained to this day and, with slight modifications, they have been in the programmes of some present-day higher schools, such as the Vilnius College even at the end of the twentieth century. The higher level of education in classical Greece was theology $y^{50}$. Greece also developed the theory of rhetoric while minding that a well-speaking man always made a good impression.

In his dialogue, Phaedrus, Plato (1996) outlined requirements to a good speech which had to be like a human being, with head, body and limbs, which meant the beginning, development and end ${ }^{51}$. A good speech had to be moderate in length and language. Referring to the opinion of the best orators of his time, such as Pericles, Thaesias, Gorgias, Trasymachos, Lysias and others, Plato put forward the opinion of Socrates that a speech had to be of a uniform composition, moderate in length and subtle, as it was a mixed use of language.

Classical antiquity developed and Aristotle wrote about three kinds of rhetoric: legal rhetoric, advisory or political rhetoric and rhetoric of display or ceremonial speeches which received the least attention ${ }^{52}$. The approach in legal speeches could be through the content of the case or through the law. The orator's

46. Ibid, Book VIII, v, 1339a26.

47. Seneca, The letters of Morality to Lucillius (trans.) D. Dilyte. In Dilyte, Dalia, 166-175. 1991.

48. Xenophon, Memories of Socrates, I.2.

49. Henrikas Zabulis, The Rhetoric of Classical Antiquity. A Course of Lectures MS (Vilnius: Vilnius University, 1995).

50. Zabulis, The Aesthetics of Classical Antiquity. A Course of Lectures MS (Vilnius: Vilnius University, 1995).

51. Plato, Faidras (trans.) Naglis Kardelis (Vilnius: Aidai, 1996).

52. Aristotle, Rhetoric, Book I. 
purpose changed accordingly: the orator could divulge, delight or move. The material in legal rhetoric had to be worked out in three stages: accumulation, presentation of the argument and oral presentation which included stylistic polish and presentation. Consequently, a speech had to have two-four parts (introduction, which could be cut, the material, the argument and conclusion) in Aristotle's conception, which gradually became three parts (introduction, development and conclusion). In his work, Rhetoric, Aristotle ${ }^{53}$ focused considerably on the theory of proof. Keeping the orator in mind, Aristotle singled out artistic and common proof (pistes atechnoi and pistes etechnoi), while the success of persuasion depended on the speaker's personal character, on the audience's disposition and on persuasive arguments in the speech ${ }^{54}$. To create the audience's favourable dispositon, the focus was kept on an introduction. In the development of a speech, the focus turned to proof. The followers of Aristotle extended the two kinds of proof defined by Aristotle, into ethical, emotional and logical proof ${ }^{55}$. Aristotle required that proof were based on three premises: the general opinion, opinion derived from evidence and that drawn from examples. He found two kinds of examples, actual facts and examples devised by the speaker, which could be fictitious.

Plato, Aristotle and, later, Quintillianus emphasised the orator's decency above all. Quintillianus made an especially strong point of orator's decency as he believed that anything could be proven with the help of words ${ }^{56}$.

Rome had a similar initial education: primary where pupils learned writing, grammar, secondary and the orator's level, which is sometimes compared with the present-day higher education ${ }^{57}$. According to Plato, Aristotle and Quintillianus, the orator had to seek extensive knowledge, as the object of rhetoric was all fields of which a speech may be required. It was not only liberal arts and subjects such as diction, convincing presentation, the ability to use tropes and figures, but also geometry and philosophy that would educate the orator. Although the Romans took over much of the rhetorical heritage of classical Greece, Cicero was the outstanding orator and author in Rome. Cicero rejected counter statements in proof and singled out five parts of a speech: introduction (proemiun), narrative (narratio), position statements (proration), proof (probatio) and rejection (refutatio). Aristotle mentioned repeatedly that he was speaking about the content of a speech, while artistic presentation of a speech mattered to Cicero,

53. Aristotle, Rhetoric. Poetics (trans.) N. Rhys Roberts and Ingram Bywater (New York: The Modern Library, 1954).

54. Ibid, ii, 4-21.

55. Zabulis, The Rhetoric of Classical Antiquity. A Course of Lectures MS, 1995.

56. Ibid; Quintillianus, "The Education of Orator."

57. Dalia Dilyte, The Pedagogues of Antiquity. Compiled by Dalia Dilyte (Kaunas: “Sviesa”, 1991). 
who introduced elocution, which meant a trained voice and exemplary articulation, as a fifth part of a speech ${ }^{58}$.

Cicero mentioned the physic of a good orator and a possibility to improve it by knowledge and training, yet warned that physical deficiencies cannot be overcome ${ }^{59}$. Cicero was sensitive to criticism of the audience, to recognition and how it could be won through training ${ }^{60}$. It was known to Cicero that all orators, even the major, feel tremor before they make a speech in public and that this is the strongest in good orators. This was not to discourage young people from studies of rhetoric, it was rather to show the ways. Cicero mentioned a confident speaker as opposed to the fearful to say that it was not too much confidence that was a virtue. If an orator could not say anything valuable to give credit to his name and win the audience's approval, he was dishonest and even his nervous disposition in making a speech could not improve his merit ${ }^{61}$.

Cicero wrote about the duty of an orator to speak convincingly, to analyse his theme with respect to its credibility, about different modes of proof in legal, advisory and ceremonial speeches and about five stages of work on a speech: the selection of a topic, its development depending on circumstances and the argument, verbal expression and polish, committing to memory and delivery ${ }^{62}$. He wrote specifically of the selection of words and composition, rhythm and metre in presentation, and the use of the voice ${ }^{63}$.

In Book II of De oratore (Cicero in Dilyte, 1991), Cicero analysed how legal speeches should be worked out depending on whether the question was general or contentious, whether the question could be treated as general or particular. Cicero acknowledged Greek orators and philosophers, especially Socrates and Aristotle $^{64}$. He emphasized that effort was essential in the training of an orator. Science could only orientate the person in training, while effort and virtue were the most important together with an insight into the richness of philosophers' language, which they developed with resort to their knowledge and verbal wealth bypassing concrete rules ${ }^{65}$. This shows one extra time that virtue, talent and decency were prized above all by classical authors, which indicates the role of work and effort as the essence of studies.

58. Zabulis, The Rhetoric of Classical Antiquity. A Course of Lectures MS, 1995.

59. Cicero, De Oratore, Book I, 25.

60. Ibid, 29.

61. Ibid, 25.

62. Ibid, 31 .

63. Ibid, 33.

64. Ibid, Book II, 38.

65. Ibid, 35. 


\section{Traditional Legacy of East European Universities}

As is obvious to the informed, the subjects in the education of children and the composition of a speech following the rules of rhetoric of classical Greece and Rome have been in the programmes of virtually all schools and universities of Western tradition to this day. Kinds of rhetoric, oratory, where it still exists, the composition of a speech and, further, the composition of any essay have been taught following the principles defined by the classical authors and philosophers mentioned above. The principles are valuable and subsequent communication by those who master the art is excellent in whatever genre of speech.

In 1995, concluding his course on aesthetics of classical antiquity, an experienced classical professor in the University of Vilnius, evaluated the education of classical antiquity by saying the following: "There is everything here, you see. It is possible to take the classical model of education and apply it in schools." Although the person held a government post and was in the position to move toward an application of the classical model of education in present-day schools, he never made a step in that direction. What has been said indicates why: it is not only that the content has changed considerably in education. It is also, and most importantly, the founding principles, especially, morality and, with it, the culture. The physical potential of man has also changed, as well as his experience, and with it, the very concepts. What God, the soul, morality and moderation mean to a Greek, a classical scholar and to a common man in Eastern Europe today, are very different things. A return to classical ideas, which can well be called ideals, may take a long way or never happen. However, it is known how education and, especially, higher education evolved in the last thirty years, following the restoration of democracy and the regaining of state independence in small East European countries.

The education that was inherited from the Soviet rule in Eastern Europe was not really broken. It had a system, was regulated by the state and had qualified professors and lecturers. If regulation, called for by Aristotle in his day, was at times extreme in Eastern Europe in the twentieth century, it ensured stability and carried along a number of positive prescriptions.

The liberation of the 1990s brought about changes in all spheres of life. Changes in education were urged most ardently by the narrow-minded and politically biased. And so, education was being reformed. Ignoring academic input and experience, systemic stability and academic achievements, reforms started, went on and have not yet finished. 


\section{Drawing on the Irreplaceable in Classical Heritage}

Withholding myself from further complaints and minding Plato's concept of the dangers of changes in the state, a reference to The Laws by Plato ${ }^{66}$ is required. In the law in question, an Athenian discusses the uses of gymnastics for the young and continues with the question of an appeal of the unusual over the usual $^{67}$.

The Athenian insists that it is important that the speaker and the listener should avoid strange and unusual things. This point takes him to the question of the state. The argument is this: it is not known in any state that the manner of games would affect the issue of laws or determine the soundness of laws in the state. A decision of the state permitting the same people to engage in the same games preserves the stability of established laws. Yet if the same games were altered and innovated by various changes because of the inclination of the young to despise the same, whether it is their bodies, dress, general opinion of the beautiful and the ugly, and to value that who is given to permanent changes, to anything new and unusual, "we would be right in assuming that nothing can be more perilous than this to the state. Such processes change delicately the habits of the young to despising the past and to adding value to novelty. There is no greater peril to the state than this like talk and thought"68. Plato's Athenian elaborates further: "If we attune the ear more sensitively to one another, we shall be aware that, except for changes in evil issues, all such changes are very dangerous" 69 . Skipping the Athenian's deliberation on changes of the seasons, bodies, thinking habits and the soul, it is relevant to focus on Plato's direct statement: "Laws under which people were educated for a long time, have become immovable because of some godly sight and nobody heard of them being altered. Every soul respects laws and fears damaging anything in them of what was formerly fixed"70. Plato's Athenian further assumes that changes in games initiated by the young are neither serious, nor vicious entertainments in themselves. That is why the young are not forbidden their innovations. Yet, any oversight of a possibility that, engaged in the new games, the young will grow different than the children of the previous generations, may lead to unwanted states. They will next seek a different life, different laws and different customs. Unlike some superficial changes, this will endanger the customs, their praise and blame will change quickly and the greatest caution will be required in this.

Whether influenced by their inclination to changes or by permanent changes in the state, the young in small new democracies in Eastern Europe have been

66. Plato, The Laws, IV-VI; Dilyte, 1991, 101-104.

67. Plato, The Laws, VII.

68. Ibid.

69. Ibid.

70. Ibid. 
becoming more and more unmanageable in schools. A practical piece of advice offers itself in the context of the present deliberation. First, the ugly and damaging sights and texts, against which ancient Greeks emphatically warned, have so polluted the space of the young through television, mass media and the internet that they have lost all emotive-intellectual balance, to say nothing of their sense of beauty. Second, schools no longer select works of literature, except the established classics, with diligence and dedication, for the young to read, probably because of the avalanche of published works and certainly because teachers are so overstrained and exhausted that they do not mind the processes. Selection was yet practiced by the postwar generation of teachers, but, as democratic liberties spread, so dedication declined. A very modern observation in this context would be that one of the reasons of the declining discipline in schools is learning without rules, which is most obvious in language learning. The idea would be that learning language with rules would teach the young discipline, accuracy and culture, while dismissing language rules leads to the opposite of these, to disobedience, aggression and impudence ${ }^{71}$. An attempt to alter the described conditions in school would combine at least two classical principles, those of selection and discipline, if we bear in mind Aristotle's recommendation that teenagers "should not lead an idle life" and that school should preserve discipline.

The first idea in this presentation to be put forward is to curb changes in education. If change is harmful to the state, change is perilous in education. The Nobel-winning economists warned against dangers of change in economy. Endless change in education means endless harm, especially when reforms last indefinitely long. And they do in some countries in Eastern Europe.

The second idea would concern the subjects. This talk is of a renewal of education, not innovation, so the past tradition has to be borne in mind. Thinking of the greatest achievers from the generation of the 1920s-1930s in statesmanship, oratory and education, remembering the precepts of classical antiquity to the useful subjects for the young, (gymnastics, arithmetic, geometry, and astronomy, by Plato; gymnastics, reading and writing, dialectic, music and drawing by Aristotle), it is relevant to remember the piece of advice that "it is required to teach not only the useful subjects, but also such subjects which reveal other subjects". Here belongs drawing, which, to Aristotle, could teach not only orientation among things but also give ideas of the theory of beauty. Music was very special to Aristotle, "the beginning of everything", as, apart from laborious engagement in its performance, music was known to give pleasure and to teach the delight of leisure ${ }^{72}$.

71. Marija L. Drazdauskiene, "Teaching Language for the Attainment of Culture," A Poster-Presentation at the $53^{\text {rd }}$ Annual International Conference of IATEFL (Liverpool, 1 April 2019).

72. Aristotle, The Politics, Book VIII, v. 
As education in oratory in Greece and later, in Rome, could have been compared to present-day higher education, it may be reiterated that orators had to seek the widest possible knowledge because the topics of speeches are unlimited, include philosophy, specifically, dialectic, the use of tropes and figures and the training of the voice. It is known that these subjects were in the curricular of EFL and literature in the University of Vilnius in the 1960s-1970s. Most of them have remained to the present-day, yet diminished. Seeking a renewal in the field, an idea would be to retain these subjects in the study of the English language, while reviving the teaching of style, which was lost with the success of pragmatics and discourse studies. Style studies have been retained in major Universities and major authors have retained the precepts of classical rhetoric in their books ${ }^{73}$. Even the newest textbooks of English and French today include the teaching of language through poems and songs, with other accents on culture and arts. That is reminiscent of the classical selection of subjects. A renewal would also require the focus on history and philosophy in literature studies. A third idea would concern memory-based learning.

A turn to memory-based learning borrowed from classical antiquity might help resurrect at least some of the basic principles and dicta, which would influence the final achievement.

In addition to what has been mentioned as possessed in higher education, may be applicable today and what exists in an impoverished form in higher education, there are more definite ideas to be drawn from classical antiquity. If present-day education can at all be compared with education in classical antiquity, we may seek ideas of its renewal in Plato's dialogue Phaedrus (Plato, 1996). Among such themes as the soul and kinds of souls, poetic madness (human madness and godly madness), ethic, erotic and logos, and criteria of a good speech, in this dialogue, Plato has Socrates deliberating on the invention of script by the Egyptians. When addressing the Egyptian ruler Tamus, the inventor of numbers, geometry, astronomy, the game of draughts and the dice as well as script, claimed that "writing will make the Egyptians wiser and of better memory, as script was a medicine for wisdom and memory"74. Socrates had a very straight and plain observation on this. In the words of the ruler of Egypt, Socrates replied: "An inventor of script, you have shown favour to the tools. You have claimed the opposite of their power. The souls of those who learn the script will gain forgetfulness because nobody will cater for memory. They will call to memory what the script prompts, exteriorly, rather than interiorly, from themselves. You

73. Cf Peter Verdonk, Stylistics (Oxford: Oxford University Press, 2002); Edward P. J. Corbett, and J. Connor Robert, Style and Statement (Oxford, New York: Oxford University Press, 1999); Donald Davidson, American Composition and Rhetoric (New York: Charles Scribner's Sons, 1968).

74. Plato, Phaedrus, 274d-275b. 
have invented a reminder rather than a medicine for memory and put forward an opinion rather than truth to your pupils"75.

This particular argument suits the $21^{\text {st }}$ century better than an inventory of any skills. It is a great loss that present-day schooling and higher education have veered away from a resort to memory. Whatever the services of the computer, it has done a major disservice to memory and to the classical tradition in education. The analogy between Socrates's story in Plato's Phaedrus of the uses of script and the function of the computer is too obvious. The loss in schools is as distinct. Students cannot overview books and papers they suppose they had read, in their graduation papers. They simply transpose fragments of text from relevant literature to their own papers. In answer to my question, whether he read the book I had lent him, one student at the University of Vilnius in the 1980s responded saying, "I have Xeroxed, i.e. photocopied, it". I have not met many young people for a long time who would be excited about the books they are supposed to be reading, excited to discuss the ideas, to hear opinions and evaluations, to argue about them, outside university.

Memory-based learning should not identify with rote-learning, of which educators forewarn today. Like the soul in the goodness of man, memory-based learning leads to the same idea of good in man. This was so in classical antiquity because reason featured in the existence of the soul. It is only immortal souls who ascend to sublimity and it is given only to them to observe what is beyond the skies. Even the poets had no access to this realm beyond. This realm is an unpalpable entity, featureless and colourless, perceivable only to reason, which is the helmsman of the soul. The right kind of cognition attaches to the soul through reason. Like God's thoughts, the thoughts of every soul which tend to feed on good, draw on and attach themselves to the realm beyond in truth and bliss ${ }^{76}$. Reason would guide man in his other decisions. It has been mentioned above that mechanical and amateur learning was unbecoming in classical antiquity. Similarly, memory-based learning should be only taken in as much as good in man requires.

\section{Conclusions}

Without a further complaint, I can say with confidence that the classical concept of learning as the process "to acquire knowledge of or skill in something through study of experience or by being taught; to commit to memory" 77 has gone out of fashion. Some dictionaries omit the sense of 'committing to memory'

75. Ibid.

76. Plato, Phaedrus, 247c-d-e; Plato, Faidras, 1996.

77. Concise Oxford English Dictionary, Twelfth Edition (ed.) Angus Stevenson and Maurice Waite. (Oxford: Oxford University Press, 2011), 811. 
from the definition of this concept altogether. There are, therefore, changes in the quality of knowledge and in the knowledge that earlier generations had had. The retiring postwar generation of teachers is the last one to have the sense of knowledge as power and knowledge as pleasure. What a pilot could do from memory with no technology assisting him in the 1940s, a language and literature student today can never do an analogous task with resort only to his memory. Whatever the grievances of the humanities, learning has gone out of fashion and, with it, the learned. Some grievances are there because the loss of humanitarian ideals may be beyond repair and because commercial levers in education go unchallenged. Through mistrust of the knowing and neglect of authority, we may also have admitted some unwanted developments ourselves, which turned to grievances in the end. Authority and trust have been damaged on two sides: on the side of society where "everyone knows everything" and on the side of personal deterioration in achievement in learning.

A late classical author, Seneca, to remember, questioned the virtues of the teaching of liberal arts and found none. Seneca stated that liberal arts do not teach morality or purity of the soul by themselves. The manner of learning in the humanities today only demonstrates that liberal arts, altered today, yet integrated in the education system, did not preclude the degradation. Only those in presentday humanities who achieve the highest proficiency esteem the subjects and the people. So, a turn to memory-based learning might be prospective and perhaps productive, if the liberal young in new democracies were attuned not only to liberties but also to responsibilities, so that discipline in schools were not treated as a violation of human rights and a task to learn as psychological pressure. In higher education, a salvation from change, the renewal of several subjects mentioned above and at least some emphasis on memory-based learning could improve the much-deplored state of the humanities today.

To be accepted, this idea about a renewal in higher education and about the three suggestions, (of a termination of reforms, a renewal of the teaching of such subjects as philosophy and logic, the history and theory of literature and style, and an introduction of memory-based learning), would require a wider publicity and discussion in teaching communities, while integrating the subjects into the curricula, the consent of the financing bodies might be required and negotiations between Deans and Heads of departments. Ongoing variations in the subjects taught would permit a replacement of such subjects as technical editing or technical translation by the subject of literature or style. If universities had given up the teaching of philosophy, logic and the history of literature altogether, the introduction of these subjects would require considerable adjustments, but could be done at the expense of sex education, gender equality or contemporary politics and similar subjects because philosophy and history might give these their minimum due of their own.

To be introduced, memory-based learning would have to be discussed and defined in the concept of classical antiquity and introduced in syllabuses by 
individual teachers. The formal task would be quite simple: it would mean assigning a certain percent (for instance, 20\%) of a subject matter for memorization. This should not be mechanical nor be seen as a scholastic measure. It has been becoming a custom initiated by the British Council in the teaching of English to expect of a teacher that he or she summarise his lessons and his courses in a couple/a few statements. It might be remembered that the best professors practiced this in the 1960s, while learning Latin sententiae by heart as part of an examination task has remained the age-old practice in some universities to this day. If such summaries as mentioned above are memorised, they might be sufficient for a lesson. Additionally, select definitions and laws would have to be committed to memory in their contexts in certain subjects. But most importantly, undergraduate students would have to be encouraged to discuss what they read for their graduation or term papers with their lecturers to be able to remember what they had read and to understand where the knowledge belongs in their own reasoning. This, inevitably, would increase the stress on the lecturer, but students still have planned classes for graduation projects, which some of them attend and some of them miss. Classes of this kind would profit from a turn to discussion of the reading matter and no special changes would be required. Viewing the state of the art rationally, the suggested changes would not appear radical. Their principles had been integrated in the programmes of many universities, so that a fresh focus would really mean only a renewal to both lecturers and administrators, while the students would, hopefully, accept a word of wisdom.

\section{Bibliography}

Aristotle. Rhetoric. Poetics. Translated by N. Rhys Roberts and Ingram Bywater. New York: The Modern Library, 1954.

Aristotle. The Politics. Translated by T. A. Sinclair. Revised and Re-Presented by Trevor S. Saunders. London: The Penguin Group, 1981.

Cicero. "De Oratore." [By Oratore.] Translated by E. Ulcinaite. In Dalia Dilyte, 139-161. 1991.

Concise Oxford English Dictionary. Twelfth Edition. Edited by Angus Stevenson and Maurice Waite. Oxford: Oxford University Press, 2011.

Corbett, Edward P. J. and Robert J. Connor. Style and Statement. Oxford, New York: Oxford University Press, 1999.

Davidson, Donald. American Composition and Rhetoric. New York: Charles Scribner's Sons, 1968.

Dilyte, Dalia. The Pedagogues of Antiquity. Compiled by Dalia Dilyte. Kaunas: "Sviesa", 1991.

Dilyte, Dalia. “The Major Teachers of Antiquity and their Theories." In Dalia Dilyte, 7-26. 1991. 
Drazdauskiene, Marija L. “Teaching Language for the Attainment of Culture." A PosterPresentation at the 53 ${ }^{\text {rd }}$ Annual International Conference of IATEFL. Liverpool, 1 April 2019.

Isocratis. Isocratis Orationes: ПPO $\triangle H M O N I K O N$, I.27-29. Lipsiae Sumptibus et Typis B. G. Teubneri. MDCCCLXIV.

Lucas, F. L. Style. London: Cassell, 1955.

Plato. The Republic of Plato. Translated by John Llewelyn Davies, M. A. and David James Vaughan, M. A. London: Macmillan and Co, 1927.

Plato. The Great Dialogues of Plato. Translated by W. H. D. Rouse. Edited by Eric H. Warmington and Philip Rouse. New York: A Mentor Book from New American Library, 1956.

Plato. Faidras. Translated from the Greek by Naglis Kardelis. Vilnius: Aidai, 1996.

Plato. "The Laws." Translated into Lithuanian by A. Kudulyte-Kairiene. In Dalia Dilyte, 95118. 1991.

Pliny. Fifty Letters of Pliny. Second Edition. Selected and Edited by A. N. Sherwin-White. Letter 36 (VII.9). Oxford, New York: Oxford University Press, 1987.

Quintillianus. "The Education of Orator." Translated into Lithuanian by A. Velickiene. In Dalia Dilyte, 176-234. 1991.

Seneca. The letters of Morality to Lucillius. Translated by D. Dilyte. In Dilyte, Dalia, 166175. 1991.

Spicer, André. Excellence is Overrated. Let's Embrace being Good Enough Instead. The Guardian, 2019.

Verdonk, Peter. Stylistics. Oxford: Oxford University Press, 2002.

Xenophon. "Memories of Socrates." Translated by Vanda Kazanskiene. In Dalia Dilyte, 3661. 1991.

Zabulis, Henrikas. The Aesthetics of Classical Antiquity. A Course of Lectures MS. Vilnius: Vilnius University, 1995.

Zabulis, Henrikas. The Rhetoric of Classical Antiquity. A Course of Lectures MS. Vilnius: Vilnius University, 1995. 